\title{
Find the real responders and improve the outcome of awake prone positioning
}

\author{
Heyan Wang ${ }^{1}\left[\right.$ and Hangyong $\mathrm{He}^{2^{*}}$
}

\section{Dear editor,}

We read with great interest of the report by Rosen and colleagues [1] about the effect of awake prone positioning (APP) on intubation rate among patients with moderate to severe hypoxemic respiratory failure (HRF) due to COVID-19. They identified a implemented protocol for APP increased duration of prone positioning, but did not reduce the rate of intubation compared to standard care. From our point of view, some details about whether APP could decrease intubation in patients with HRF due to COVID-19 need to be further clarified.

First, in Rosen's study [1], the patient in standard care group also received a median prone duration of $3.4 \mathrm{~h}$ compared with $9.0 \mathrm{~h}$ per day in the prone group, which means that the real intervention factor they investigated was whether a prolonged APP could further decrease intubation rate. Therefore, it may be more appropriate to draw a conclusion that prolonged APP did not reduce the rate of intubation in patients with HRF due to COVID-19.

Second, Rosen and colleagues [1] reported a 33\% intubation rate in both groups, which is much lower than that reported in two other studies $[2,3]$ with similar baseline characteristics, degree of respiratory failure but shorter APP duration (41\% and $49 \%$ in the control group and $40 \%$ and $58 \%$ in the prone group) compared with their investigation. Based on this data, could we speculate that prolonged APP does decrease the intubation rate?

Third, in Rosen's study [1], most patients were put on APP when they were supported with noninvasive ventilation, which is a higher level support than high flow nasal canula (HFNC) [4]. This may indicate that they use the APP more like a "rescue" therapy rather than an "adjunctive" therapy in a late stage of ARF, which may get less response to APP and therefore less difference in intubation rate.

In summary, combining this lack of accuracy of comparison of APP and non-APP patients, and the possibly late initiation of APP in the moderate to severe ARF COVID-19 patients, a priori chance of finding a difference in intubation was low and may explain the negative findings for the APP. And further analysis with data from comparison of non-APP populations and prolonged APP group, especially in patients support with HFNC and prolonged APP, is needed for a more settled conclusion.

*Correspondence: yonghang2004@sina.com

${ }^{2}$ Department of Respiratory and Critical Care Medicine, Beijing

Institute of Respiratory Medicine, Beijing Chao-Yang Hospital, Capital

Medical University, No. 8 Gongren Tiyuchang Nanlu, Chaoyang District, Beijing 100020, China

Full list of author information is available at the end of the article

Comment on: Jacob Rosén, Erik von Oelreich, Diddi Fors, Malin Jonsson Fagerlund, Knut Taxbro, Paul Skorup, Ludvig Eby, Francesca Campoccia Jalde, Niclas Johansson, Gustav Bergström, Peter Frykholm, PROFLO Study Group. Awake prone positioning in patients with hypoxemic respiratory failure due to COVID-19: the PROFLO multicenter randomized clinical trial. Crit Care. 2021, 25:209. (https://doi.org/10.1186/s13054-021-03602-9. Published on: 14 June 2021).

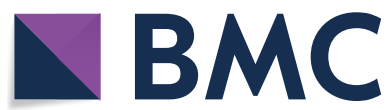

This article is licensed under a Creative Commons Attribution 4.0 International License, which permits use, sharing, (tistribution and reproduction in any medium or format, as long as you give appropriate the source, provide a link to the Creative Commons licence, and indicate if changes were made. The images or other third party material in this article are included in the article's Creative Commons licence, unless indicated otherwise in a credit line to the material. If material is not included in the article's Creative Commons licence and your intended use is not permitted by statutory regulation or exceeds the permitted use, you will need to obtain permission directly from the copyright holder. To view a copy of this licence, visit http://creativecommons.org/licenses/by/4.0/. The Creative Commons Public Domain Dedication waiver (http://creativecommons.org/publicdomain/zero/1.0/) applies to the data made available in this article, unless otherwise stated in a credit line to the data. 


\section{Acknowledgements}

None.

\section{Authors' contributions}

$\mathrm{HW}$ and $\mathrm{HH}$ are responsible for study design and writing. Both authors read and approved the final manuscript.

\section{Funding}

None.

\section{Availability of data and materials}

Not applicable.

\section{Declarations}

Ethics approval and consent to participate

Not applicable.

\section{Consent for publication}

Not applicable.

\section{Competing interests}

The authors declare that they have no competing interests.

\section{Author details}

${ }^{1}$ Department of Critical Care Medicine, The Sixth Hospital of Guiyang, Guiyang City, Guizhou Province, China. ${ }^{2}$ Department of Respiratory and Critical Care Medicine, Beijing Institute of Respiratory Medicine, Beijing Chao-Yang Hospital, Capital Medical University, No. 8 Gongren Tiyuchang Nanlu, Chaoyang District, Beijing 100020, China.
Received: 27 June 2021 Accepted: 30 June 2021

Published online: 08 July 2021

\section{References}

1. Rosen J, von Oelreich E, Fors D, Jonsson Fagerlund M, Taxbro K, Skorup P, Eby L, Campoccia Jalde F, Johansson N, Bergstrom G, et al. Awake prone positioning in patients with hypoxemic respiratory failure due to COVID-19: the PROFLO multicenter randomized clinical trial. Crit Care. 2021:25(1):209.

2. Ferrando C, Mellado-Artigas R, Gea A, Arruti E, Aldecoa C, Adalia R, Ramasco F, Monedero P, Maseda E, Tamayo G, et al. Awake prone positioning does not reduce the risk of intubation in COVID-19 treated with high-flow nasal oxygen therapy: a multicenter, adjusted cohort study. Crit Care. 2020;24(1):597.

3. Padrao EMH, Valente FS, Besen B, Rahhal H, Mesquita PS, de Alencar JCG, da Costa MGP, Wanderley APB, Emerenciano DL, Bortoleto FM, et al. Awake prone positioning in COVID-19 hypoxemic respiratory failure: exploratory findings in a single-center retrospective cohort study. Acad Emerg Med. 2020;27(12):1249-59.

4. Ding L, Wang L, Ma W, He H. Efficacy and safety of early prone positioning combined with HFNC or NIV in moderate to severe ARDS: a multi-center prospective cohort study. Crit Care. 2020;24(1):28.

\section{Publisher's Note}

Springer Nature remains neutral with regard to jurisdictional claims in published maps and institutional affiliations.
Ready to submit your research? Choose BMC and benefit from:

- fast, convenient online submission

- thorough peer review by experienced researchers in your field

- rapid publication on acceptance

- support for research data, including large and complex data types

- gold Open Access which fosters wider collaboration and increased citations

- maximum visibility for your research: over 100M website views per year

At $\mathrm{BMC}$, research is always in progress.

Learn more biomedcentral.com/submissions 